\title{
A GDP és a nemzeti számlák revíziójának hazai gyakorlata, okai és eredményei
}

Szőkéné Boros Zsuzsanna,

a KSH főosztályvezetője

E-mail: Zsuzsanna.Boros@ksh.hu
A tanulmány bemutatja a statisztikai termékek, ezen belül a nemzeti számlák területén érvényesített revíziók indokait, típusait, a felülvizsgálat elönyeit és hátrányait. Ezt követően ismerteti az utóbbi évek hazai revíziós gyakorlatát, a nemzeti számlák és a bruttó hazai termék területén. Végül röviden elemzi a felülvizsgálatok hatását a bruttó hazai termék folyó áras adataira és volumenindexére vonatkozóan.

TÁRGYSZÓ:

Nemzeti számla.

Bruttó hazai termék.

Revíziós politika.

DOI: 10.20311/stat2017.06.hu0557 
A nemzeti számlák rendszere a gazdaságstatisztika olyan központi eleme, amely összefüggő, konzisztens keretet nyújt a makrogazdasági folyamatok összegzéséhez és elemzéséhez. Ahhoz, hogy ezt a szerepet maradéktalanul betölthesse, és megfelelhessen a felhasználók igényeinek, naprakész rendszerként kell múködtetni, folyamatosan biztosítva közben a stabilitást, valamint az időbeli és nemzetközi összehasonlíthatóságot is. Fontos követelmény a rendszerrel szemben - mint minden más, a hivatalos statisztika által elóállított termék esetében -, hogy minél jobb minőségben, minél gyorsabban álljanak az adatok a felhasználók rendelkezésére.

Mindezek teljesítése nagy kihívás elé állítják az adatok összeállítóit, a statisztikusokat. A valós folyamatok mérése, a rendszer módszertanának folyamatos naprakészen tartása nem kedvez a stabilitásnak, a gyorsaság ronthatja a minőséget. Mindezen követelményeknek teljesítése érdekében a statisztikusoknak folyamatosan módosítaniuk, revideálniuk kell az adatokat. Az újonnan fontossá váló jelenségek megfigyelése és mérése céljából, illetve a nemzetközileg egyeztetett metodikai követelmények változása miatt szükséges a módszertanokat változtatni. Másrészt a rendelkezésre álló információk körének, mennyiségének és minőségének időbeli bővülése következtében pontosítani, finomítani kell a becsléseket. E tényezők teszik szükségessé a revíziókat. A felhasználókat általában zavarja az adatmódosítás, hiszen felül kell bírálniuk az eddig ismert adatokból levonható következtetéseiket, ugyanakkor jogosan igénylik a minőségi adatokat. A statisztikusok viszont úgy tekintenek a felülvizsgálatra, hogy az javítja az adatok minőségét, hiszen a felülvizsgálat során újabb, teljesebb körü információkat, továbbfejlesztett módszertanokat felhasználva a valóságot jobban tükröző adatokhoz jutnak, amelyek elemzéséböl pontosabb következtetéseket lehet levonni, a döntéseket biztosabban lehet megalapozni. Ehhez viszont az szükséges, hogy a statisztikusok minél több információval szolgálják a felhasználókat a revíziókra vonatkozóan. Előzetesen nyilvánosságra hozott és a gyakorlatban követett felülvizsgálati politikával kell rendelkezni, a módosított adatok publikálásakor szükséges részletes magyarázatot biztosítani, és a lehető legkevesebbre kell korlátozni a revíziók számát.

A következőkben bemutatjuk, hogy a nemzeti számlák, ezen belül elsősorban a GDP-számítás (gross domestic product - bruttó hazai termék) területén miként sikerült megfelelni az elvárásoknak a hazai gyakorlatban. 


\section{A revíziókról általában, revíziós politika}

Adatrevízióról csak a már lezárt és publikált adatok esetében beszélhetünk. A változások okai lehetnek (Hüttl-Pozsonyi [2001]):

- újabb, pontosabb, részletesebb adatok jutottak tudomásunkra;

- külső vagy belső okok miatt a statisztikai módszertan változott;

- adathiba miatt utólagos javításra van szükség;

- bázisváltással járó súlyváltozás, és más hasonló módszertani okok miatt technikai korrekcióra van szükség.

Az Európai Unióban elfogadott irányelvek említett okok miatti revíziói a következő típusokba sorolhatók (Eurostat [2013a]):

1. Rutinreviziók: olyan változások a publikált adatokban, melyek a rendszeres adat-előállítási folyamathoz kapcsolódnak (például szakértői becsléssel pótolt hiányzó adatok lecserélése az időközben már jelentett adatokra). Jellemző rájuk a gyakoriság és a rendszeresség. Szokásosan ezeket a revíziókat egy, a revíziós politikában meghatározott, előre rögzített és nyilvános publikációs/revíziós naptár szerinti ütemezésben publikálják (például amikor egy új adat közlése megtörténik, azzal egy időben az előző időszak revideált adatát is publikálják).

A rutinrevíziók szükségessége különböző okokra vezethető vissza: az aktuális, minél gyorsabban elérhető információk növekvő igényére (melynek ,ára” a rendszeres rutinrevízió), az alkalmazott becslési módszertan statisztikai adottságaira, az alapinformációk revízióira stb.

2. Nagyrevíziók: a publikált adatok olyan - gyakran lényeges - változásai, melyek a következő okokra vezethetők vissza:

- Olyan új strukturális adatforrás válik elérhetővé, mely csak hosszabb időközönként (5-10 év) áll rendelkezésre. Ilyenek a cenzusok, input-output táblák, munkaerőköltség-felmérések stb.

- Egy indexsor bázisévének súlyait frissítik. Erre általában öt évente kerül sor.

- Változnak az idősor előállításakor használt fogalmak, definíciók és/vagy osztályozások.

- Új, az adat előállítást érintő jogszabály lép érvénybe, például a nemzeti számlák új módszertana, az ESA 2010 bevezetésekor, 2014-ben. 
Az adatok elöállítói a nagyrevíziókat gyakran összekötik a módszertani fejlesztések bevezetésével is, melynek előnye, hogy így elkerülhető az adatok túl gyakori revideálása. Éppen ezért általános, hogy a nagyrevíziók nemcsak egy okra, hanem azok kombinációjára vezethetők vissza. Az adat-elóállítók feladata, hogy az egyes okok hatását elkülönítve is bemutassák a revízió során.

A felhasználókat a nagyrevíziókról időben elöre tájékoztatni kell, jelezve, hogy az adatokban jelentős változás következhet be. Mivel a nagyrevíziók gyakran az idősor jelentős részét vagy teljes idősorokat érintenek, így szükséges, hogy ilyenkor a teljes idősorra visszavezetve revideálják az adatokat annak érdekében, hogy elkerüljék az idősorokban fellépö töréseket vagy inkonzisztenciát.

3. Nem tervezett reviziók: az adatok olyan, elöre be nem jelentett változásai, melyeknek oka valamilyen elöre nem látható körülmény, mint például a hibák vagy véletlen események, illetve a revíziók előre rögzített ütemezésének hiánya. A nem tervezett jelző nem a revízió okára, hanem az időzítés hiányára utal. Ebből következik, hogy a nem tervezett revíziókat nem jelentik be előre, és nem rögzítik a tájékoztatási tervben sem.

A nem tervezett revíziók összezavarhatják a felhasználókat és alááshatják a statisztikába vetett bizalmukat, így lehetőség szerint ezek alkalmazását el kell kerülni és az olyan esetekre korlátozni, amikor fontos és jelentős hibák kijavítását célozzák

4. Évjárat (vintage) követése: Az évjárat- vagy valós idejü adatbázis egy olyan statisztikai tárház, mely az adatok archív publikációit tartalmazza, így az adatok két tetszőleges publikálási időpont közötti változása megismerhetővé, azonosíthatóvá válik. Az évjárat-adatbázis metainformációi tartalmazzák a nem tervezett revíziók körülményeit is, melyet az adatok revíziós elemzésekor figyelembe kell venni. Mivel az adatok évjáratverzióinak tárolása és azok valós idejü feldolgozása és összevetése erőforrás-igényes feladat, ezért ezek az évjáratadatbázisok általában csak a változók egyes csoportjairól (kulcs indikátorok) tartalmaznak részletes információkat.

5. Reviziós elemzés: A revíziós elemzés fontos eszköz az adatelőállítók számára, mivel alapvető információkat szolgáltat az adatok, valamint az adat-előállítás módszertanának és folyamatának minőségéről. Az elözetes adatok revíziójában jelentkező torzítás vagy az adatok szokatlan viselkedése feltárhat szisztematikus anomáliákat, illetve az adatgyüjtés és -elóállitás azon területei azonosíthatók vele, melyeket szükséges fejleszteni. Lényeges, hogy ne csak a fö aggregátumokra 
végezzük el a revíziós elemzést, hanem az azok alapadatául szolgáló idősorokra is az adatminőség további javítása érdekében.

A revíziós analízis másik fontos célja, hogy kvantitatív információkat szolgáltasson a revíziókról annak érdekében, hogy a felhasználók meggyőződhessenek az adatok általános minőségéröl. Ilyen kvantitatív információk az adatok pontossága, megbízhatósága, stabilitása (revíziók száma egy adott intervallumon belül).

A revíziók típusainak rendszerbe foglalását, időbeli ütemezését nevezzük revíziós politikának. A jól megtervezett és nyilvánosságra hozott revíziós politika a felhasználók és a statisztikusok számára is segítséget nyújt az adatok közötti eligazodásban, értelmezésében. Nehezíti a helyzetet, hogy a különböző szakstatisztikák közötti revíziók összhangjának megteremtését még nemzetközi szinten sem sikerült megoldani, bár hosszú évek óta próbálják az egyes országok revíziós gyakorlatát, politikáját harmonizálni. Az említett elveket szinte minden országban - föleg az Európai Unió tagországaiban - követik, részben pont az Unió előírásai, részben a tagországok eltérő lehetőségei miatt, azonban a teljes harmonizáció jelen helyzetben lehetetlennek tünik. Eltérő adatátadási időpontok vonatkoznak az uniós gazdaság- és monetáris politikaalkotáshoz szükséges statisztikákra. Például a fizetési mérleget a tagországoknak már $T+85$ napra kell küldeni, a negyedéves külföld számlát pedig $T+90$ napra. Így előfordulhat, hogy ebben az újabb információk alapján az export-import adatok változnak, eltérve $T+60$ napra átadott negyedéves GDP-ben szereplö külkereskedelmi adattól. Hasonlóképpen a tavaszi EDP (excessive deficit procedure - az Európai Unió túlzott hiány eljárása) miatt március végén változik a kormányzati szektor valamely adata, de ezt nem tudjuk érvényesíteni a negyedéves nemzeti számlákban, csak szeptemberben, az éves számlák összeállításakor. Ebben az időpontban viszont már megint frissülnek a kormányzati szektor adatai.

A nemzeti számlák területén, nemzetközi szinten 2016-ban tettek kísérletet a harmonizációra. A CMFB- (Committee on Monetary, Financial and Balance of Payments Statistics - Monetáris, Pénzügyi és Fizetésimérleg-bizottság) munkacsoport a nemzeti számlák és a fizetési mérleg revíziós politikájának összehangolásával foglalkozott. A DMES- (Directors of Macroeconomic Statistics, Eurostat Makroökonómiai Statisztika Igazgatói) munkacsoport a nemzeti számlák benchmark $^{1}$ revízióit (nagyrevízióit) próbálta egységesíteni. Mindkét munkacsoport elkészítette javaslatát, melyekben még mindig meglehetősen szabad választást engedtek a tagországoknak a javasolt felülvizsgálati politikától való eltérést illetően, elismerve a gyakorlatban meglevő különbözőségeket.

\footnotetext{
${ }^{1}$ A benchmark módszer alatt azt értjük, hogy egy évre vonatkozóan nagyon részletes számítás készül, majd a további évekre (5 vagy 10 évre) ezeket az adatokat indikátorok vagy proxyk felhasználásával továbbvezetjük. Ebben az esetben a benchmark év megválasztása kulcskérdés, a tapasztalat azt mutatja, hogy minél régebbi a benchmark, annál nagyobb változás valószínủ az új benchmark évre történő váltás idején. E gyakorlat összehangolására törekedett a már említett DMES-munkacsoport.
} 


\section{A nemzeti számlák és a GDP revíziós politikája a hazai gyakorlatban}

A KSH 2011-ben módosította utoljára a nemzeti számlák revíziós politikáját, melynek legföbb eleme a nyitott évek (amelyekre még nincs éves forrásból számított adat) negyedéves adatainak rendszeres revíziója volt. Ez lehetővé tette a legfrissebb alapadatok beépítését a nemzeti számlákba és a felhasználók folyamatos tájékoztatását.

\section{1. Éves számlák}

Az első éves számokat a negyedéves számításokból becsüljük. Elöször a GDP volumenindexe készül el $T+45$ (ahol $T$ a tárgyidőszak utolsó napja) ${ }^{2}$ napra (február közepére). Utána $T+60 / 65$ napra a folyó áras adatokat is összeállítjuk, és újra számoljuk a volumenindexeket is. Mivel az éves adatok ekkor a negyedéves adatok összegzésével állnak elő, részletezettségük megegyezik a negyedéves számításokéval, azaz a GDP termelés, felhasználás elemeit folyó és változatlan áron, valamint a jövedelem keletkezése számlát folyó áron publikáljuk.

A teljes számlarendszert éves szinten jelenleg egy alkalommal állítjuk össze, az éves alapadatforrások és módszerek felhasználásával. A revíziós politika szempontjából is fontos hangsúlyozni, hogy a magyar gyakorlatban általánosan nem alkalmazzuk az ún. benchmark módszert. A hazai gyakorlat felfogható az évenkénti benchmark módszerének is, hiszen évente a rendszer minden elemét alapadatok felhasználásával újrabecsüljük. Ily módon a hazai gyakorlatban nagyrevízión a nagyobb volumenü módszertani változások bevezetését értjük, nem beszélhetünk klasszikus értelemben vett benchmark-váltásról. Miután a változatlan áras számítások előző évi árakon készülnek, a bázisváltás sem része a nagyrevíziónak.

Az éves nemzeti számlák - hazai és nemzetközi - publikálási ideje minden év szeptember 30., a $t-1$ évre vonatkozóan. Ebben az esetben a teljes számlarendszert összeállítjuk folyó áron, és meghatározott elemeit (a GDP termelési és felhasználási oldalának elemeit és a GNI-t [gorss national income - bruttó nemzeti jövedelem]) változatlan áron is. Ebben az időpontban van lehetőség az éves adatok revíziójára, rutinrevízió (azaz a felhasznált alapadatforrásokban bekövetkezett változások, illetve hibajavitás) miatt $t-2$ évre, a forrás-felhasználás táblák integrálása (ami valójában rutinrevíziónak számít) miatt $t-3$ évre, az esetleges módszertani fejlesztések miatt pedig a teljes idősorra vonatkozóan.

\footnotetext{
${ }^{2}$ A publikálás időpontja a tárgyidőszak utolsó napját követő 45. nap.
} 
Az éves nemzeti számlák reviziói

\begin{tabular}{|c|c|c|c|c|}
\hline \multirow{2}{*}{$\begin{array}{l}\text { Referencia- } \\
\text { időszak }\end{array}$} & \multirow[b]{2}{*}{ Típus } & \multicolumn{2}{|c|}{ A publikálás ideje* } & \multirow[b]{2}{*}{ Megjegyzés } \\
\hline & & $\begin{array}{c}\text { Tárgyidőszak végét }(T) \\
\text { követő nap }\end{array}$ & Hónap & \\
\hline \multirow{2}{*}{$t$. év } & \multirow{2}{*}{\begin{tabular}{|} 
Negyedéves számítá- \\
sok alapján első \\
becslés, IV. negyed- \\
évvel egy időben
\end{tabular}} & \multirow{2}{*}{$T+45 / 60$ nap } & \multirow{2}{*}{$\begin{array}{l}t+1 \text { év } \\
\text { február/március }\end{array}$} & $\begin{array}{c}\text { Negyedéves becslésnek } \\
\text { megfelelö részletezettségben }\end{array}$ \\
\hline & & & & $\begin{array}{c}\text { Revízió: } t \text {. év negyedévei } \\
\text { változhatnak }\end{array}$ \\
\hline \multirow[t]{2}{*}{$t$. év } & \multirow[t]{2}{*}{$\begin{array}{c}\text { Éves nemzeti számlák, } \\
\text { második előzetes } \\
\text { becslés }\end{array}$} & \multirow[t]{2}{*}{$T+9$ hónap } & \multirow[t]{2}{*}{$\begin{array}{c}t+1 \text { év } \\
\text { szeptember vége }\end{array}$} & $\begin{array}{l}\text { Éves adatforrásokból, éves } \\
\text { módszertan alapján, teljes } \\
\text { számlasorozat, } \\
\text { GDP változatlan ár }\end{array}$ \\
\hline & & & & Revízió: $t, t-1, t-2$ \\
\hline \multirow[t]{2}{*}{ t. év } & \multirow[t]{2}{*}{$\begin{array}{c}\text { Éves nemzeti számlák, } \\
\text { felülvizsgált becslés }\end{array}$} & \multirow[t]{2}{*}{$T+21$ hónap } & \multirow[t]{2}{*}{$\begin{array}{c}t+2 \text { év } \\
\text { szeptember vége }\end{array}$} & $\begin{array}{l}\text { Éves adatforrásokból, éves } \\
\text { módszertan alapján, teljes } \\
\text { számlasorozat, } \\
\text { GDP változatlan ár }\end{array}$ \\
\hline & & & & Revízió: $t+1, t, t-1$ \\
\hline \multirow[t]{2}{*}{ t. év } & \multirow{2}{*}{\begin{tabular}{|} 
Éves nemzeti számlák \\
forrás-felhasználás \\
táblák alapján felül- \\
vizsgált becslés
\end{tabular}} & \multirow[t]{2}{*}{$T+33$ hónap } & \multirow[t]{2}{*}{$\begin{array}{c}t+3 \text { év } \\
\text { szeptember vége }\end{array}$} & $\begin{array}{l}t \text { t. évre vonatkozó forrás- } \\
\text { felhasználás táblák alapján } \\
\text { összeállított becslés }\end{array}$ \\
\hline & & & & Revízió: $t+2, t+1, t$ \\
\hline
\end{tabular}

* $T+45$ napra a GDP volumenindexét, $T+60 / 65$ napra a GDP-t folyó és előző évi áron, termelési, felhasználási és jövedelem oldalról publikáljuk.

\subsection{Negyedéves számlák}

A negyedéves nemzeti számlákat negyedévente kétszer publikáljuk. Ezek egyike sem fedi le a teljes számlarendszert, a nemzetközi követelményeknek megfelelően, de nem teljesen összhangban a hazai felhasználói igényekkel.

Az első becslés $T+45$ napra készül a GDP volumenindexére vonatkozóan termelési oldalról, tényadatokra alapozva, illetve modellek felhasználásával.

A második becslés a $T+60$ napra készül el, és naptári napoktól függően a 63-65. napon publikáljuk. Ennél a közlésnél folyó és változatlan áras adatokat, volumenindexeket számítunk a GDP termelési, felhasználási oldaláról, valamint folyó áron a jövedelem oldaláról, a részaggregátumokra vonatkozóan is.

A nemzeti számlák érvényes felülvizsgálati politikája alapján 2012 eleje óta a folyó év negyedéveire és az azt megelőző évre - amennyiben erre vonatkozóan éves 
adatforrásokon alapuló adatokat még nem publikáltunk, azaz az ún. „nyitott évekre” - a GDP-adatok negyedévenkénti adatjavítása visszamenőleges megtörténik. A 2. táblázat mutatja az egyes közléseknél végrehajtott revíziókat.

2. táblázat

\begin{tabular}{|c|c|c|c|c|}
\hline \multirow[b]{2}{*}{ Referencia-időszak } & \multirow[b]{2}{*}{ Típus } & \multicolumn{2}{|c|}{ A publikálás ideje } & \multirow[b]{2}{*}{ Revízió } \\
\hline & & $\begin{array}{l}\text { Tárgyidőszak végét } \\
\text { (T) követő nap }\end{array}$ & Hónap & \\
\hline \multirow{2}{*}{ t. év I. negyedéve } & $\begin{array}{l}\text { Negyedéves GDP } \\
\text { gyorsbecslés }\end{array}$ & $T+45$ nap & május közepe & nincs \\
\hline & $\begin{array}{l}\text { Negyedéves GDP } \\
\text { második becslés }\end{array}$ & $T+60 / 65$ nap & június eleje & $\begin{array}{c}t \text { t. év I. negyedéve } T+45 \text { napos } \\
\text { becslése változhat }\end{array}$ \\
\hline \multirow[b]{2}{*}{ t. év II. negyedéve } & $\begin{array}{l}\text { Negyedéves GDP } \\
\text { gyorsbecslés }\end{array}$ & $T+45$ nap & $\begin{array}{l}\text { augusztus } \\
\text { közepe }\end{array}$ & nincs \\
\hline & $\begin{array}{l}\text { Negyedéves GDP } \\
\text { második becslés }\end{array}$ & $T+60 / 65$ nap & $\begin{array}{l}\text { szeptember } \\
\text { eleje }\end{array}$ & $\begin{array}{c}t . \text { év I. negyedéve } \\
\text { és a II. negyedév } T+45 \text { napos } \\
\text { becslése változhat }\end{array}$ \\
\hline \multirow[t]{2}{*}{ t. év III. negyedéve } & $\begin{array}{l}\text { Negyedéves GDP } \\
\text { gyorsbecslés }\end{array}$ & $T+45$ nap & $\begin{array}{l}\text { november } \\
\text { közepe }\end{array}$ & $\begin{array}{c}t-3, t-2, t-1 \text { év összes } \\
\text { negyedéve, } \\
\text { és } t \text {. év I. és II. negyedéve }\end{array}$ \\
\hline & $\begin{array}{l}\text { Negyedéves GDP } \\
\text { második becslés }\end{array}$ & $T+60 / 65$ nap & december eleje & $\begin{array}{c}t . \text { év III. negyedéve } \\
T+45 \text { napos becslése változhat }\end{array}$ \\
\hline \multirow[b]{2}{*}{ t. év IV. negyedéve } & $\begin{array}{c}\text { Negyedéves GDP } \\
\text { gyorsbecslés }\end{array}$ & $T+45$ nap & február közepe & nincs \\
\hline & $\begin{array}{l}\text { Negyedéves GDP } \\
\text { második becslés }\end{array}$ & $T+60 / 65$ nap & március eleje & $\begin{array}{c}t \text {. év I-III. negyedéve } \\
\text { és a IV. negyedév } T+45 \text { napos } \\
\text { becslése változhat }\end{array}$ \\
\hline
\end{tabular}

A 2. táblázatból látható, hogy a III. negyedév első becslésekor kerül sor a negyedéves idősor visszaigazítására a tárgyévet megelőző év(ek) éves adatához.

Az alkalmazott gyakorlat előnye, hogy így a nemzeti számlákban gyorsabban megjeleníthetők az újabb és pontosabb alapadatok, ezáltal minőségében jobb, konzisztensebb képet adhatunk a gazdasági folyamatokról, azok évközi alakulásáról. A kialakított gyakorlat az Eurostat ajánlásainak is jobban megfelel. Hátránya, hogy év közben többször változhatnak a nyitott évek negyedéves adatai. Fontos azonban megjegyezni, hogy a változások mértéke szük intervallumon belül mozog.

A negyedéves adatok visszamenőleges korrigálására kizárólag adathibákból, alapadat-változásból eredően (rutinjavításként) van lehetőség, mint például az év közben a mezőgazdaságra vonatkozó, folyamatosan frissülő adatok beépítése. Mód- 
szertani fejlesztéseket továbbra is csak az éves adatok szeptemberi revíziója során lehet bevezetni.

A szezonálisan kiigazított adatokat minden negyedévben felülírja az utolsó futtatás, a szezonális kiigazítás természetéből fakadóan. A szezonális kiigazítás paramétereinek beállítására az I. negyedévi adatok közlése előtt kerül sor.

\section{A revíziók hatása a GDP folyó áras adataira és volumenindexeire}

A revízióspolitika egyik alapelve - ahogy azt az előzőkben már említettük -, hogy a felhasználókat mindig tájékoztassuk a felülvizsgálatok okáról és mértékéről. Ez a tájékoztatás történhet a revíziót megelőzően, például egy nagy módszertani váltás esetében, illetve utólag is, a módosított adatok publikálásával egy időben. A legjobb megoldás - ha a lehetőségek engedik -, hogy mindkét alkalmat felhasználjuk, mint ahogy történt 2014-ben az ESA 2010, ${ }^{3}$ a nemzeti számlák új módszertanának bevezetésekor a hazai és a nemzetközi gyakorlatban.

Fontos ugyanakkor, hogy a statisztikák előállítói is rendelkezzenek a revíziókkal kapcsolatos információkról. Ehhez szolgál eszközül az 1. fejezetben említett évjáratok követése eszköz, amely segítségével figyelemmel kísérhető, hogy egyik publikálástól a másikig milyen irányban és mértékben változtak az adatok.

Az évjáratok követése eszköz sokféle lehet, az Excel táblától az adatbázisokon alapuló elemzésekig. Mint már említettük, az évjáratelemzés nagy erőforrás- és időigényes feladat. A KSH-ban hosszú évek óta követjük figyelemmel a GDP revízióit a nemzeti számlák összeállítása során.

A revíziók elemzésekor érdemes külön figyelmet szentelni a folyó áras adatoknak és a volumenindexeknek. Az egyes felülvizsgálatok eredményei másként érinthetik ezeket. Nehezítheti az elemzést, hogy a nemzeti számlák esetében a hazai gyakorlatban a revíziók különbözö típusainak hatását a folyó áras adatokon lehet kimutatni. A változatlan áras számítások már az összes változást tartalmazó folyó áras adatokra készülnek, így a volumenindexek is az összes változás hatását mutatják.

Ennek alapján a következőkben külön vizsgáljuk a GDP folyó áras adatainak változását a revíziók hatására és külön a volumenindex változását.

A 3. táblázat a magyar éves GDP folyó áras adatainak változását mutatja a 2013. évi szeptemberitől a legutóbbi, 2016. szeptemberi éves publikálásig. A márciusi

\footnotetext{
${ }^{3}$ Az Európai Parlament és a Tanács 549/2013/EU rendelete (2013. május 21.) az Európai Unió-beli nemzeti és regionális számlák európai rendszeréről. Az Európai Unió Hivatalos Lapjának honlapján a hivatalos európai uniós nyelveken is elérhető a rendelet. http://eur-lex.europa.eu/legal-content/HU/TXT/?uri= OJ:L:2013:174:TOC
} 
publikálás az első, $t-1$ évre vonatkozó éves adat, amely a negyedéves számításokból ered. A júniusi publikálási idő a $t$. év I. negyedéves adatainak közlési ideje, ahol a nyitott évek $(t-1)$ adatai még változhatnak. Erre példa a 2015. júniusi közlés, ahol a 2014. évi adatok 26 milliárd Ft-tal csökkentek. A szeptemberi a $t-1$ évi adatok éves módszertan szerinti publikálása.

3. táblázat

A folyó áras GDP-adatok változása a revíziók hatására, 2001-2015 (millió Ft)

\begin{tabular}{l|c|c|c|c|c|c|c|c}
\hline \multirow{2}{*}{ Tárgyév } & \multicolumn{7}{|c|}{ A publikálás ideje } \\
\cline { 2 - 9 } & $\begin{array}{c}2016 . \\
\text { szeptember }\end{array}$ & $\begin{array}{l}2016 . \\
\text { június }\end{array}$ & $\begin{array}{c}2016 . \\
\text { március }\end{array}$ & $\begin{array}{c}2015 . \\
\text { szeptember }\end{array}$ & $\begin{array}{c}2015 . \\
\text { június }\end{array}$ & $\begin{array}{c}2015 . \\
\text { március }\end{array}$ & $\begin{array}{c}2014 . \\
\text { szeptember }\end{array}$ & $\begin{array}{c}2013 . \\
\text { szeptember }\end{array}$ \\
\hline 2001 & 11544 & - & - & 35250 & - & - & 232750 & - \\
\hline 2002 & 11541 & - & - & 38740 & - & - & 251880 & - \\
\hline 2003 & 11613 & - & - & 58345 & - & - & 269177 & - \\
\hline 2004 & 10830 & - & - & 98185 & - & - & 249597 & - \\
\hline 2005 & 11602 & - & - & 127900 & - & - & 313017 & - \\
\hline 2006 & 14192 & - & - & 104203 & - & - & 359587 & - \\
\hline 2007 & 21739 & - & - & 91751 & - & - & 456973 & - \\
\hline 2008 & 33753 & - & - & 88799 & - & - & 406011 & - \\
\hline 2009 & 38712 & - & - & 83814 & - & - & 548406 & - \\
\hline 2010 & 34205 & - & - & 105665 & - & - & 432998 & -94307 \\
\hline 2011 & 32289 & - & - & 98793 & - & - & 399598 & -250966 \\
\hline 2012 & 32629 & - & - & 79089 & - & - & 500732 & -204178 \\
\hline 2013 & 62344 & - & - & 218746 & - & - & 768447 & \\
\hline 2014 & 220482 & - & - & 315697 & -26633 & & & \\
\hline 2015 & 287172 & - & & & & & & \\
\hline
\end{tabular}

A 3. táblázat alapján megállapítható, hogy mely időpontokban zajlott jelentős módszertani váltás, és mely években hajtottunk végre csak rutinrevíziót. Például látszik, hogy 2014, 2015 és 2016 szeptemberében is történt módszertani váltás, amelyet az egész idősoron átvezettünk, míg 2013 szeptemberében csupán rutinrevíziót hajtottunk végre, hiszen 3 év adata módosult. Ezek a következtések annak a ténynek az ismeretében vonhatók le természetesen, ha tudjuk, a nemzeti számlákban a módszertani revíziókat a rendelkezésre álló idősoron végig kell vezetni az összehasonlíthatóság érdekében.

A 2014 szeptemberében megfigyelhető nagymértékủ változások oka a már említett ESA 2010 bevezetése volt. A változásokról részletesen írtunk a Statisztikai Szemlében is (Pozsonyi-Szökéné Boros [2014]). 
Összefüggésben a korábbi években bevezetett változásokkal (például a saját előállítású szoftverek és adatbázisok, eredeti példányok, a nem megfigyelt gazdaság becslése) 2015-ben a módszertan további finomhangolására volt szükség (KSH [2015]), 2016 szeptemberében pedig a hitelintézetek esetében elszámolt konverziós díjat (a devizaátváltás külön nem kimutatott díja) vezettük át a rendszeren ( $K S H$ [2016]).

A 4. táblázat a revíziók relatív hatását mutatja, azaz a változást az előző GDPadat százalékában. Ennek ismeretében jobban megítélhető a módosítások hatása.

4. táblázat

A revíziók hatása a folyó áras GDP-adatokra a GDP százalékában, 2001-2015 (százalék)

\begin{tabular}{l|c|c|c|c|c|c|c|c}
\hline \multirow{2}{*}{ Tárgyév } & \multicolumn{7}{|c}{ A publikálás ideje } \\
\cline { 2 - 9 } & $\begin{array}{c}2016 . \\
\text { szeptember }\end{array}$ & 2016. június & $\begin{array}{c}2016 . \\
\text { március }\end{array}$ & $\begin{array}{c}2015 . \\
\text { szeptember }\end{array}$ & 2015. június & $\begin{array}{c}2015 . \\
\text { március }\end{array}$ & $\begin{array}{c}2014 . \\
\text { szeptember }\end{array}$ & $\begin{array}{c}2013 . \\
\text { szeptember }\end{array}$ \\
\hline 2001 & 0,1 & - & - & 0,2 & - & - & 1,5 & - \\
\hline 2002 & 0,1 & - & - & 0,2 & - & - & 1,5 & - \\
\hline 2003 & 0,1 & - & - & 0,3 & - & - & 1,4 & - \\
\hline 2004 & 0,1 & - & - & 0,5 & - & - & 1,2 & - \\
\hline 2005 & 0,1 & - & - & 0,6 & - & - & 1,4 & - \\
\hline 2006 & 0,1 & - & - & 0,4 & - & - & 1,5 & - \\
\hline 2008 & 0,1 & - & - & 0,4 & - & - & 1,8 & - \\
\hline 2009 & 0,1 & - & - & 0,3 & - & - & 2,1 & - \\
\hline 2010 & 0,1 & - & - & 0,4 & - & - & 1,6 & $-0,4$ \\
\hline 2011 & 0,1 & - & - & 0,4 & - & - & 1,4 & $-0,9$ \\
\hline 2012 & 0,1 & - & - & 0,3 & - & - & 1,8 & $-0,7$ \\
\hline 2014 & 0,2 & - & - & 0,7 & - & - & 2,6 & - \\
\hline
\end{tabular}

A folyó áras adatok alapján a revíziók mértéke jelentősnek tünik, de ha megnézzük a revíziók GDP-hez viszonyított arányát, már árnyaltabb kép rajzolódik ki. Látható, hogy igazán jelentős revízió 2014-ben történt az ESA 2010 bevezetésével, ahol a GDP 1,2 és 2,1 százaléka között szóródnak a változások. A 2014-ben megfigyelhető 2,6 százalékos és a 2013-ben látható 1,8 százalékos változás tartalmazza a rutinrevíziók hatását is. Ilyen mértékủ módszertani változásokra azonban csak ritkán kerül sor, általában 10-15 évente vizsgálják felül a nemzetközi szervezetek a nagy, nemzetközi módszertanokat. Elképzelhető, hogy gyorsan változó világunkban szükségessé válik a módszertanok gyakoribb változtatása, korrigálása, hiszen évente több új 
jelenség tünik fel, amelyek kezelésére a meglevő rendszerek nem adnak megfelelő útmutatást. A gyors változásokat viszont ilyen bonyolult, nemzetközileg harmonizált rendszerek lassan tudnák követni.

Mint már említettük, a folyó áras adatok esetében ki lehet külön mutatni a különböző típusú revíziók miatti változást. Az éves adatok közlésekor a KSH publikálja is a változások részletezését a „Magyarország nemzeti számlái” kiadványokban. Ennek alapján például 2014-2016-ban a revíziók típusa szerint a következőképpen változtak a folyó áras GDP adatai:

5. táblázat

A folyó áras GDP változása a reviziók hatására a reviziók tipusa szerint, 2010-2014 (százalékpont)

\begin{tabular}{|c|c|c|c|c|c|c|c|c|c|c|c|c|}
\hline \multirow{4}{*}{ Revízió típusa } & \multicolumn{12}{|c|}{ Tárgyév } \\
\hline & \multicolumn{3}{|c|}{2010} & \multicolumn{3}{|c|}{2011} & \multicolumn{3}{|c|}{2012} & \multicolumn{2}{|c|}{2013} & 2014 \\
\hline & \multicolumn{12}{|c|}{ A publikálás ideje } \\
\hline & 2014 & 2015 & 2016 & 2014 & 2015 & 2016 & 2014 & 2015 & 2016 & 2015 & 2016 & 2016 \\
\hline $\begin{array}{l}\text { Módszertani változások } \\
\text { (nagyrevízió) }\end{array}$ & 1,5 & 0,4 & 0,1 & 1,3 & 0,4 & 0,1 & 2,0 & 0,4 & 0,1 & 0,4 & 0,1 & 0,1 \\
\hline $\begin{array}{l}\text { Rutinrevízió miatti } \\
\text { változások }\end{array}$ & 0,1 & 0,0 & 0,0 & 0,1 & 0,0 & 0,0 & $-0,2$ & 0,1 & 0,0 & 0,3 & 0,1 & 0,6 \\
\hline Összesen & 1,6 & 0,4 & 0,1 & 1,4 & 0,4 & 0,1 & 1,8 & 0,5 & 0,1 & 0,7 & 0,2 & 0,7 \\
\hline
\end{tabular}

Az 5. táblázat adatai szerint 2014-ben a rutinrevíziók aránya a korábbi évekhez hasonló mértékủ, a jelentős változást a módszertani váltás okozta. A rutinrevíziók okozta változás mindig az utolsó három évet érinti, egyre kisebb mértékben. Ugyanakkor megfigyelhető, hogy a 2014. évi publikáláskor az utolsó év (2012) folyó áras GDPadata a rutinrevízió miatt 0,2 százalékponttal lett kisebb, míg a 2016. évi publikáláskor az utolsó év (2014) GDP-je 0,6 százalékponttal lett magasabb ugyanezen okból.

A folyó áras adatokban megjelenő változások érintik a GDP volumenindexét is, amely kiemelten fontos mutató, a gazdaság teljesítményének alakulásáról ad információt. A GDP volumenváltozását használják gazdaságpolitikai döntések meghozatalához, előrejelzések készítéséhez, elemzésekhez. A gazdaságpolitikai döntések alátámasztásához elsősorban minél nagyobb gyakoriságú (negyedéves) és a tárgyidőszakot követő minél gyorsabban rendelkezésre álló adatokra van szükség. Az elemzésekhez, előrejelzésekhez viszont minél jobb minőségü, lehetőleg stabil idősorok szükségesek. Ahogy már említettük, a gyorsaság és a pontosság általában csak egymás rovására valósíthatók meg, tehát a revízió elkerülhetetlen. A gyorsaságpontosság feszültség feloldásához segítséget jelenthet a revíziók elemzése. 
Láttuk, hogy a folyó áras GDP esetében rendelkezésre állnak a szükséges adatok, és szétválaszthatók a különféle okokból végrehajtott adatmódosítások hatásai. A változatlan áras GDP-t azonban az összes revízió eredőjét tartalmazó folyó áras GDP-adatokból számítjuk. Ennek okán nem tudjuk kimutatni a változások volumenindexre gyakorolt hatását a revíziók típusa szerint, csupán összesítve.

A 6. táblázat mutatja be 2001 és 2015 között az éves GDP-volumenindex módosulásait a különböző adatközlések idején. (Ebben a táblában nem tüntettük fel a júniusi adatközléseket, mivel mint a folyó áras adatoknál láttuk, csak egy helyen változott a folyó áras adat is, és annak volumenindexre gyakorolt hatása 0 .)

6. táblázat

Az éves GDP-volumenindex változása a reviziók hatására, 2001-2015

(százalékpont)

\begin{tabular}{l|c|c|c|c|c|c}
\hline \multirow{2}{*}{ Tárgyév } & \multicolumn{7}{|c}{ A publikálás ideje } \\
\cline { 2 - 7 } & $\begin{array}{c}2016 . \\
\text { szeptember }\end{array}$ & $\begin{array}{c}2016 . \\
\text { március }\end{array}$ & $\begin{array}{c}2015 . \\
\text { szeptember }\end{array}$ & $\begin{array}{c}2015 . \\
\text { március }\end{array}$ & $\begin{array}{c}2014 . \\
\text { szeptember }\end{array}$ & $\begin{array}{c}2013 . \\
\text { szeptember }\end{array}$ \\
\hline 2001 & $-0,1$ & - & 0,1 & - & 0,0 & - \\
\hline 2002 & 0,0 & - & 0,0 & - & 0,0 & - \\
\hline 2003 & 0,0 & - & 0,1 & - & $-0,1$ & - \\
\hline 2004 & 0,1 & - & 0,2 & - & 0,0 & - \\
\hline 2005 & 0,0 & - & 0,1 & - & 0,3 & - \\
\hline 2006 & 0,1 & - & $-0,2$ & - & 0,1 & - \\
\hline 2007 & 0,0 & - & $-0,1$ & - & 0,4 & - \\
\hline 2009 & 0,1 & - & 0,0 & - & 0,0 & - \\
\hline 2010 & 0,0 & - & 0,0 & - & 0,2 & $-0,3$ \\
\hline 2011 & $-0,1$ & - & $-0,1$ & - & $-0,3$ & $-0,1$ \\
\hline 2012 & 0,0 & - & $-0,1$ & - & 0,2 & 0,1 \\
\hline 2014 & 0,1 & - & $-0,2$ & - & 0,2 & \\
\hline 2015 & 0,2 & - & 0,4 & - & 0,4 & \\
\hline
\end{tabular}

A márciusi közlések a negyedéves becslésekből származnak, revíziós politikánknak megfelelően ezekben az időpontokban nem történik felülvizsgálat. A 2014 szeptemberében publikált adatok mutatják a már többször említett ESA 2010 módszertani váltás volumenindexre gyakorolt hatását (beleértve a rutinrevíziók hatását is). Látható, hogy míg az új módszertanra való áttérés a GDP szintjét megemelte 1-2 százalékponttal, a volumenindexre jóval kisebb hatást gyakorolt. A további években végrehajtott kisebb mértékü módszertani változások is megjelennek a volumenindexekben, a hatásuk 0,1-0,2 százalékpont. 
Az utóbbi évtizedben a negyedéves GDP iránti felhasználói igény egyre erősödik. Szemléltetésképpen, míg 2005-ben a gyorsbecslés $T+60$ napra készült, és a részletes becslést $T+70$ napra publikálta a KSH, addig napjainkra a gyorsbecslés ideje $T+45$ napra rövidült, és a részletes becslés is elérhető $T+65$ nap környékén (tulajdonképpen akkor, mint tíz évvel ezelőtt a gyorsbecslés). Az Eurostat 2016-tól az Európai Unióra és az eurozónára már $T+30$ napra közzéteszi a GDP volumenindexére vonatkozó gyorsbecslését. Mivel az adatgyüjtéseket nem lehet az egyre rövidülő határidőkhöz igazítani, az adatszolgáltatók nem tudnak ilyen gyorsan adatot szolgáltatni, a statisztikai hivatalok nem tudják ilyen gyorsan feldolgozni a rendelkezésre álló adatokat, ezért matematikai-statisztikai, ökonometriai módszerekre kell támaszkodni a gyorsbecslések készítése során. Ez természetesen maga után vonja az adatrevíziókat, hiszen aztán később az adatgyüjtésekből származó eredmények értelemszerüen eltérhetnek a becslési eredményektöl. Stabil gazdasági, szabályozási környezetben az eltérés általában minimális, de a mai gyorsan változó világban ez egyre kevésbé teljesül.

A hazai gyakorlatban is igaz, hogy mindig a rendelkezésre álló legfrissebb adatokat használjuk az aktuális becslésekhez, és a revíziós politika alapján építjük be az újabb adatokat a számításokba. Így a negyedéves adatokat jóval gyakrabban módosítjuk, mint az évest.

A 7. táblázat összefoglalóan mutatja a negyedéves GDP-volumenindex változásának főbb ismérveit, a 2005. évi adatoktól kezdődően.

7. táblázat

A reviziók hatása a negyedéves GDP volumenindexére, 2005-2015

\begin{tabular}{l|c|c|c|c|c|c}
\hline \multirow{2}{*}{$\begin{array}{c}\text { Év, } \\
\text { negyedév }\end{array}$} & $\begin{array}{c}\text { Változások } \\
\text { száma } \\
\text { (darab) }\end{array}$ & \multirow{2}{*}{$\begin{array}{c}\text { Összes változás } \\
\text { (százalékpont) }\end{array}$} & Maximum & \multicolumn{4}{|c|}{ Minimum } & Medián & Átlag \\
\cline { 4 - 7 } 2005. I. & 9 & 0,0 & 0,8 & $-0,4$ & 0,0 & 0,0 \\
\hline 2005. II. & 9 & 0,3 & 0,8 & $-0,5$ & 0,0 & 0,0 \\
\hline 2005. III. & 9 & 0,0 & 0,8 & $-0,5$ & 0,0 & 0,0 \\
\hline 2005. IV. & 10 & 0,6 & 0,8 & $-0,5$ & 0,0 & 0,1 \\
\hline 2006. I. & 7 & $-0,3$ & 0,3 & $-0,4$ & 0,0 & 0,0 \\
\hline 2006. II. & 9 & $-0,3$ & 0,2 & $-0,3$ & 0,0 & 0,0 \\
\hline 2006. III. & 8 & 0,0 & 0,3 & $-0,4$ & 0,0 & 0,0 \\
\hline 2006. IV. & 7 & 0,4 & 0,5 & $-0,4$ & 0,0 & 0,1 \\
\hline 2007. I. & 7 & $-1,0$ & 0,4 & $-0,7$ & 0,0 & $-0,1$ \\
\hline 2007. II. & 6 & $-1,0$ & 0,4 & $-0,7$ & 0,0 & $-0,2$ \\
\hline 2007. III. & 8 & $-0,8$ & 0,4 & $-0,7$ & 0,0 & $-0,1$ \\
\hline 2007. IV. & 6 & $-0,8$ & 0,4 & $-0,7$ & 0,0 & $-0,1$ \\
\hline
\end{tabular}

(A táblázat folytatása a következö oldalon.) 


\begin{tabular}{|c|c|c|c|c|c|c|}
\hline \multirow{2}{*}{$\begin{array}{c}\text { Év, } \\
\text { negyedév }\end{array}$} & \multirow{2}{*}{$\begin{array}{c}\text { Változások } \\
\text { száma } \\
\text { (darab) }\end{array}$} & \multirow{2}{*}{$\begin{array}{c}\text { Összes változás } \\
\text { (százalékpont) }\end{array}$} & Maximum & Minimum & Medián & Átlag \\
\hline & & & \multicolumn{4}{|c|}{ (százalék) } \\
\hline 2008. I. & 6 & 0,4 & 0,2 & $-0,1$ & 0,0 & 0,1 \\
\hline 2008. II. & 4 & 0,4 & 0,2 & 0,0 & 0,0 & 0,1 \\
\hline 2008. III. & 6 & 0,9 & 0,6 & $-0,1$ & 0,0 & 0,2 \\
\hline 2008. IV. & 4 & 0,0 & 0,1 & $-0,2$ & 0,0 & 0,0 \\
\hline 2009. I. & 4 & $-0,3$ & 0,2 & $-0,4$ & 0,0 & $-0,1$ \\
\hline 2009. II. & 4 & $-0,3$ & 0,2 & $-0,5$ & 0,0 & $-0,1$ \\
\hline 2009. III. & 4 & $-0,3$ & 0,2 & $-0,4$ & 0,0 & $-0,1$ \\
\hline 2009. IV. & 4 & $-0,1$ & 0,3 & $-0,3$ & 0,0 & 0,0 \\
\hline 2010. I. & 5 & $-0,5$ & 0,1 & $-0,3$ & 0,0 & $-0,1$ \\
\hline 2010. II. & 5 & $-0,5$ & 0,1 & $-0,3$ & 0,0 & $-0,1$ \\
\hline 2010. III. & 5 & $-0,5$ & 0,1 & $-0,3$ & 0,0 & $-0,1$ \\
\hline 2010. IV. & 5 & $-0,6$ & 0,1 & $-0,3$ & 0,0 & $-0,1$ \\
\hline 2011. I. & 5 & 0,2 & 0,3 & $-0,1$ & 0,0 & 0,0 \\
\hline 2011. II. & 4 & $-0,1$ & 0,2 & $-0,2$ & 0,0 & 0,0 \\
\hline 2011. III. & 4 & 0,1 & 0,2 & $-0,1$ & 0,0 & 0,0 \\
\hline 2011. IV. & 3 & 0,0 & 0,2 & $-0,1$ & 0,0 & 0,0 \\
\hline 2012. I. & 4 & 0,2 & 0,2 & $-0,2$ & 0,0 & 0,1 \\
\hline 2012. II. & 5 & 0,0 & 0,2 & $-0,2$ & 0,0 & 0,0 \\
\hline 2012. III. & 4 & $-0,1$ & 0,2 & $-0,2$ & 0,0 & 0,0 \\
\hline 2012. IV. & 3 & 0,1 & 0,2 & $-0,2$ & 0,0 & 0,0 \\
\hline 2013. I. & 3 & 0,6 & 0,3 & 0,0 & 0,0 & 0,2 \\
\hline 2013. II. & 3 & 1,2 & 0,7 & 0,0 & 0,1 & 0,4 \\
\hline 2013. III. & 3 & 1,0 & 0,4 & 0,0 & 0,1 & 0,3 \\
\hline 2013. IV. & 3 & 1,2 & 0,5 & 0,0 & 0,3 & 0,4 \\
\hline 2014. I. & 2 & 0,5 & 0,4 & 0,0 & 0,0 & 0,3 \\
\hline 2014. II. & 2 & 0,6 & 0,4 & 0,0 & 0,1 & 0,3 \\
\hline 2014. III. & 3 & 0,6 & 0,4 & 0,0 & 0,1 & 0,2 \\
\hline 2014. IV. & 2 & 0,3 & 0,4 & $-0,1$ & 0,0 & 0,1 \\
\hline 2015. I. & 1 & 0,2 & 0,2 & 0,2 & 0,2 & 0,2 \\
\hline 2015. II. & 1 & 0,2 & 0,2 & 0,2 & 0,2 & 0,2 \\
\hline 2015. III. & 1 & 0,2 & 0,2 & 0,2 & 0,2 & 0,2 \\
\hline 2015. IV. & 1 & 0,2 & 0,2 & 0,2 & 0,2 & 0,2 \\
\hline
\end{tabular}

A változások száma azt mutatja, hogy az adott időszakra vonatkozó adatok első publikálása óta hány alkalommal módosult az adat. Az összes változás azt jelenti, hogy az első közlés és az eddigi utolsó közlés adata között mennyi az eltérés. Például 
a 2012. II. negyedévi GDP-volumenindex a 2013. májusi első közlés óta öt alkalommal változott, viszont az összes változás értéke 0,0 százalékpont. A 2008. III. negyedévi adat összesen hat alkalommal módosult, és az összes változás 0,9 százalékpont. Ezek, amint már említettük, a rutinrevízió és a módszertani változások hatását együttesen mutatják.

A revíziók mélyebb elemzéséhez megnéztük a szélsőértékeket, azaz mely negyedévekben tapasztalható akár pozitív (maximum), akár negatív irányú (minimum) változás. A legnagyobb pozitív irányú változás 2015 negyedéveiben történt, de az összes változás $0,0-0,6$ százalékpont. A legnagyobb negatív irányú változást 2007ben figyelhetjük meg, ebben az évben az össze változás is nagymértékü, $-1,0$ és $-0,8$ százalékpont közötti. Megjegyezzük, hogy ennek módszertani oka van, a változások a 2011 szeptemberében számított és közölt éves adatokban jelennek meg. Ekkor vezettünk át több módszertani váltást a nemzeti számlákon, például a forrásfelhasználás táblák integrálását és ezzel a kiegyensúlyozás új módszertanát.

A változások mediánja általában 0 százalékpont, ahogy közeledünk a tárgyidőszakhoz kezd más értéket felvenni, például 2013 IV. negyedévében 0,3 százalékpont lett. Ez azt mutatja, hogy inkább nem változnak az adatok, mint igen, és a változások gyakorisága csökken az idő előrehaladtával, az adott negyedévre vonatkoztatva.

A revíziók átlaga pedig azt mutatja meg, hogy átlagosan milyen mértékben módosult az adott negyedévre vonatkozó GDP-volumenindex adata. Például 2013. IV. negyedévben az átlagos változás is jelentős, 0,4 százalékpont. Ez a legmagasabb átlagérték a vizsgált időszakban, az esetek többségében ez 0 vagy 0,1 százalékpont.

A revíziókat nagyon sok szempont szerint lehet még elemezni. Megnézhetjük például, hogy a különböző időszakok között miként változott az idősor, mely időszakokban figyelhető meg jelentős változás, előfordul-e valamilyen szabályszerüség a revíziók folyamatában. Az 1. ábra például azt mutatja meg, hogyan változott a negyedéves GDP volumenindexe a 2001-2014. évek negyedéveire vonatkozóan a 2014 III. negyedéve és 2016 IV. negyedéve között végrehajtott revíziók hatására. Láthatjuk, hogy a legnagyobb mértékben 2013 és 2014 negyedévei változtak a vizsgált időszakban, különösen az I. és IV. negyedév. Ezen kívül még a 2005. IV. negyedévi adatokban figyelhető meg magasabb változás. Ebből látszik az is, hogy a 7. táblázatban kimutatott $0,5-1,2$ százalékpontos összes változás nagyobb része 2014 III. negyedéve előtt történt. Ez arra utal, hogy a negyedéves indexeket általában jobban mozgatják az adatforrások frissítése miatti változások, mint a módszertani felülvizsgálatok. Ennek oka az lehet, hogy a módszertani változások nagyságrendileg nagyjából azonos mértékben érintik az egyes évek adatait, és így a volumenindexekben kevésbé jelenik meg a hatásuk. Ugyanakkor a rutinrevízió miatti változások nagyságrendileg eltérők az egyes években, így nagyobb hatást gyakorolnak az indxekre. 


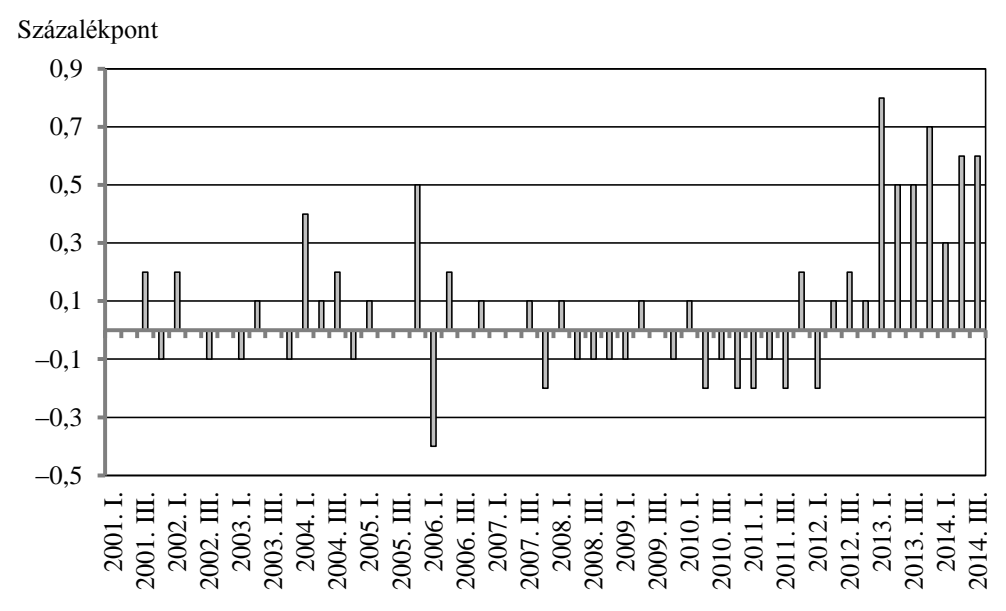

év, negyedév

A revíziók szabályszerüségére az eddigi elemzésekben nem találtunk bizonyítékot. A 2. ábra az éves GDP volumenindexének összes változását mutatja, azaz azt, hogy az első és jelenlegi utolsó publikáció között összesen hány százalékponttal változott az index, és az átlagos változást, vagyis azt, hogy egy revízió átlagosan mennyivel módosította a volumenindexet.

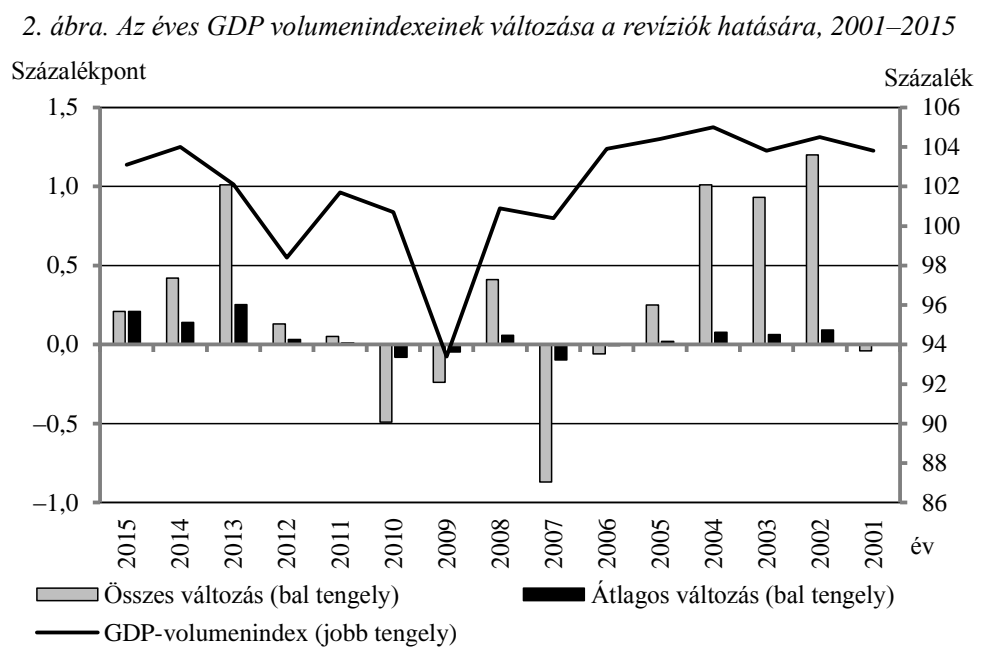

Mélyebb elemzés hiányában egyelöre annyit állapíthatunk meg, hogy egyrészt pozitív és negatív korrekciók egyaránt előfordulnak, másrészt ezen korrekciók iránya 
nem feltétlenül esik egybe a GDP-volumenindexek időbeli lefutásával. Azaz nem állíthatjuk, hogy visszaesés esetén negatív a revízió, növekedéskor pedig pozitív.

Az elkövetkező időkben a KSH a revíziók elemzésének folytatását, bővítését és az eredmények publikálását is tervezi.

A revíziók elemzését ebben a cikkben elsősorban az adat-előállítók szempontjából mutattuk be. A nemzeti számlák - akár éves, akár negyedéves - összeállításakor mindig arra törekszünk, hogy a legfrissebb, teljes körü, legjobb minőségű információkat használjuk fel a becsléshez. Mivel az adatok köre folyamatosan változik, óhatatlan, hogy a becslések eredménye is változzon. Továbbá az alkalmazott módszertant is igazítani kell a változó gazdasági körülményekhez, követni kell a nemzetközi módszertani ajánlások változásait, ami szintén befolyásolja az eredményeket. A statisztikusoknak is, a felhasználóknak is együtt kell élni az adatok változásával. A statisztikusok feladata, hogy lehetőség szerint minden szükséges információt a felhasználók rendelkezésére bocsássanak az adatok értelmezéséhez, elemzéséhez. Az adatok elemzésénél figyelembe kell venni, hogy a hazai gyakorlatban még mindig nem áll rendelkezésre kellő hosszúságú idősor, és a felgyorsult változásokhoz a statisztika nehezen tud alkalmazkodni. Ugyanakkor az eltelt húsz évben a módszertan sokat fejlődött, a korábbi időszakokban, főleg a negyedéves becslés kezdetekor tapasztalható nagyfokú bizonytalanságok megszüntek, illetve minimálisra csökkentek. A statisztikai termékek, köztük a nemzeti számlák és a GDP minőségének egyik mutatója a revíziók száma és mértéke. Célunk, ahogy eddig is, a revíziók számának és mértékének minimalizálása, az adatok minőségének megtartása, javítása mellett.

\section{Irodalom}

Eurostat [2013a]: ESS Quidelines on Revision Policy for PEEIs - 2013 edition. Luxembourg. http://ec.europa.eu/eurostat/en/web/products-manuals-and-guidelines/-/KS-RA-13-016

Eurostat [2013b]: Handbook on Quarterly National Accounts. Luxembourg. http://ec.europa.eu/ eurostat/documents/3859598/5936013/KS-GQ-13-004-EN.PDF/3544793c-0bde-4381-a7ada $5 \mathrm{cfe} 5 \mathrm{~d} 8 \mathrm{c} 8 \mathrm{~d} 0$

HÜttl A. - Pozsonyi P. [2001]: Gondolatok a felülvizsgálati politikáról. Statisztikai Szemle. 79. évf. 8. sz. 653-668. old.

KSH (KöZPOnti Statisztikai Hivatal) [2014]: Magyarország Nemzeti Számlái, 1995-2013. Budapest.

KSH [2015]: Magyarország Nemzeti Számlái, 1995-2014. Budapest.

KSH [2016]: Magyarország Nemzeti Számlái, 1995-2015. Budapest.

Pozsonyi P. - SZABÓ P. [2010]: Új fejlesztések a nemzeti számlákban. Statisztikai Szemle. 88. évf. 3. sz. 236-251. old.

POZSONYI P. - SZÖKÉNÉ BOROS Zs. [2014]: A nemzeti számlák európai rendszerének változása - az ESA 2010 bevezetése. Statisztikai Szemle. 92. évf. 11-12. sz. 954-971. old. 


\section{Summary}

The paper gives an overview of the reasons, types, advantages and disadvantages of national account and GDP revisions. It introduces the Hungarian revision policy and also analyses the effects of revisions on current price data and volume indices of Hungarian GDP from data compliers' point of view. 